\title{
ASPEK REPRODUKSI IKAN BAUNG(Hemibagrus nemurus) DI PAPARAN BANJIRAN LUBUK LAMPAM KABUPATEN OGAN KOMERING ILIR
}

\section{REPRODUCTIVEASPECT OF GREEN CATFISH (Hemibagrus nemurus) IN LUBUK LAMPAM FLOODPLAIN, OGAN KOMERING ILIR REGENCY}

\author{
Eko Prianto ${ }^{1}$, Mohammad Mukhlis Kamal' ${ }^{2}$, Ismudi Muchsin ${ }^{2}$ dan Endi Setiadi Kartamihardja ${ }^{1}$ \\ ${ }^{1}$ Pusat Penelitian dan Pengembangan Perikanan \\ ${ }^{2}$ Fakultas Perikanan dan Ilmu Kelautan Institut Pertanian Bogor \\ Teregistrasi I tanggal: 07 Oktober 2015; Diterima setelah perbaikan tanggal: 02 Desember 2015; \\ Disetujui terbit tanggal: 04 Desember 2015 \\ e-mail: eko_pesisir@yahoo.com
}

\begin{abstract}
ABSTRAK
Ikan baung (Hemibagrus nemurus) merupakan salah satu jenis ikan ekonomis penting di perairan umum daratan Indonesia khususnya Kabupaten Ogan Komering Ilir. Ikan ini memiliki nilai ekonomis penting untuk ikan konsumsi. Pada tahun 2004 hasil tangkapan ikan baung di Sumatera Selatan berjumlah 1.684,6 ton sedangkan pada tahun 2005 berjumlah 899,5 ton. Penelitian ini bertujuan untuk mengetahui aspek reproduksi ikan baung di paparan banjiran. Lokasi penelitian di Lubuk Lampam Kabupaten Ogan Komering Ilir Provinsi Sumatera Selatan dimulai bulan Nopember 2012-Nopember 2013. Ikan sampel dikumpulkan dari hasil tangkapan nelayandan hasil tangkapan percobaan dengan menggunakan alat tangkap jaring insang (gill net), pancing (pole and line), bubu dan bengkirai (traps). Analisis data meliputi: nibah kelamin, tingkat kematangan gonad, indek kematangan gonad, ukuran pertama kali matang gonad, potensi reproduksi dan pola reproduksi. Sampel ikan baung berjumlah 384 ekor terdiri dari jantan dan betina masing-masing sebanyak 118 dan 266 ekor. Hasil penelitian menunjukkan nisbah kelamin ikan baung yang ditemukan dalam penelitian baung 0,44:1, yang menunjukkan nibah kelamin tidak seimbang. Nilai IKG ikan baung betina berkisar 1,8-14.3\% sedangkan ikan baung 1,3-3,9\%. Ukuran pertama kali $(\mathrm{Lm})$ ikan yang matang gonad untuk baung jantan $(232 \mathrm{~mm})$ dan betina $(332 \mathrm{~mm})$. Rata-rata fekunditas ikan baung berjumlah $47.882 \pm 13.624$ dengan pola pemijahannya adalah serempak.
\end{abstract}

\section{KATA KUNCI: Aspek reproduksi, ikan baung, Lubuk Lampam}

\begin{abstract}
Baung (Hemibagrus nemurus) is one of the economically important fish species in Indonesiainland water, especially Ogan Ilir district. These fish have an important economic value as fish consumption. In 2004, production of baung in South Sumatra amount 1684.6 tons decreased to 899.5 tons in 2005. The aim of this research was to determine some aspects of reproductiveof green catfish in floodplain. The research location in a Lubuk Lampam floodplain Ogan Ogan Ilir South Sumatra began in November 2012-November 2013. Fish samples were collected by experimental fishing such gill nets, pole and line, traps. Data analysis includes sex ratio, level maturity, gonado somatic index, first maturity, reproductive potential and reproductive patterns. Green catfish samples have totally 384 specimen consist of males and females, 118 and 266 specimen, respectively. The results showed sex ratio of the male and female of green catfish was 0.44: 1, which shows the sex ratio is unbalanced. Gonado somatic index value of green catfish female ranged 1.8-14.3\% while male was 1.3-3.9\%. The size at the first maturity of the male and female of green catfish was 232 and $332 \mathrm{~mm}$, repectively. The fecundity average of green catfish range $47.882 \pm 13.624$ and the spawning pattern of green catfish was classified into total spawner.
\end{abstract}

\section{KEYWORD : Reproductive aspect, green catfish, Lubuk Lampam}

\section{PENDAHULUAN}

Ikan baung (Hemibagrus nemurus) merupakan salah satu jenis ikan ekonomis penting di perairan umum daratan Indonesia khususnya Kabupaten Ogan Komering Ilir. Ikan ini sangat digemari masyarakat dan memiliki nilai ekonomis penting untuk ikan konsumsi dalam bentuk ikan olahan maupun ikan segar. Permintaan ikan baung dipasaran setiap tahunnya cenderung mengalami peningkatan sehingga upaya penangkapannya di alam secara intensif terus dilakukan nelayan. Menurut Hadid et al. (2014) hasil tangkapan ikan baung di Sumatera Selatan mengalami penurunan, pada tahun 2004 hasil tangkapan ikan baung berjumlah 1.684,6 ton sedangkan pada tahun 2005 berjumlah 899,5 ton. Peningkatan penangkapan di alam tidak sebanding dengan upaya budidayanya. Budidaya dan pemijahan ikan baung telah berhasil dilakukan dibeberapa tempat, namun belum berkembang dengan baik. Saat ini, masyarakat masih mengandalkan pasokan kebutuhan ikan baung dipasaran berasal dari usaha penangkapan. 
Daerah penyebaran ikan baung terdapat di kawasan tropika yang meliputi Afrika, Asia Tenggara dan Asia Timur (Kottelat et al. 1993). Di Indonesia tersebar di Pulau Sumatera, Kalimantan dan Jawa (Djajadiredja et al. 1977). Habitat ikan baung selain perairan tawar, sungai dan danau juga ditemukan di perairan payau, muara sungai dan umumnya ditemukan didaerah paparan banjiran. Ikan baung menyukai habitat perairan yang keruh, hidup bergerombol di dasar perairan serta bersembunyi di dalam sarang atau tempat yang gelap sebelum malam hari. Setelah malam hari ikan ini akan keluar dari sarang untuk mencari makan (Sukendi, 2001). Ikan baung tergolong kedalam ikan omnivora yang cenderung karvivora dengan makanan terdiri dari anak ikan, udang, insekta, moluska dan rumput (Djajadiredja et al. 1977; Samuel dan Adjie, 1994).

Seiring dengan meningkatnya kegiatan penangkapan dan eksploitasi ikan baung di perairan umum daratan tanpa upaya konservasi, maka populasi ikan ini semakin menurun. Disamping itu, pencemaran lingkungan dan cara penangkapan yang tidak sesuai ikut mempertajam penurunan populasi ikan baung di alam. Tekanan lingkungan yang terjadi di rawa banjiran Lubuk Lampam berdampak terhadap biota perairan yang hidup di area tersebut. Ikan khas rawa banjiran menggunakan paparan rawa banjiran terutama sebagai area pemijahan dan pengasuhan. Hal ini juga sangat terkait dengan pola pergerakan atau distribusi ikan di kawasan rawa banjiran sebagai suatu strategi reproduksi maupun adaptasi terhadap perubahan kondisi lingkungan (Jubaedah, 2015). Informasi aspek reproduksi ikan baung sangat penting di dalam pengembangan budidaya dimasa mendatang, sehingga data dan informasinya sangat diperlukan dalam menyusun strategi pengelolaannya.

Penelitian ini bertujuan untuk mengetahui beberapa aspek reproduksi ikan baung di paparan banjiran Lubuk Lampam. Hasil penelitian ini diharapkan dapat menjadi informasi tambahan dalam upaya pengelolaan sumberdaya ikan baung agar dapat dimanfaatkan secara optimal dan berkelanjutan.

\section{METODEPENELITIAN \\ Waktu dan Lokasi Pengambilan Sampel}

Penelitian ini dilakukan di paparan banjiran Lubuk Lampam Kabupaten Ogan Komering Ilir Provinsi Sumatera Selatan (Gambar 1) dimulai bulan Nopember 2012 hingga Nopember 2013. Ikan sampel dikumpulkan dari hasil tangkapan nelayan/enumerator dan hasil tangkapan percobaan dengan menggunakan alat tangkap jaring insang (gill net), pancing (pole and line), bubu dan bengkirai (traps) di Sungai Lempuing Lubuk Lampam. Jumlah sampel ikan baung yang diperoleh selama penelitian berjumlah 384 ekor dan rata-rata sampel dianalisa sebanyak 29 ekor/bulannya. Pengukuran data tinggi muka air $(\mathrm{cm})$ menggunakan papan ukur yang diamati setiap satu bulan sekali oleh enumerator. Pengukuran tinggi muka air bertujuan untuk mengetahui dinamika (trend) perubahan muka air secara musiman yang terjadi di paparan banjiran. Terjadinya perubahan muka air secara musiman mempengaruhi tingkah laku pemijahan ikan, sehingga dapat diketahui waktu ikan mulai memijah.

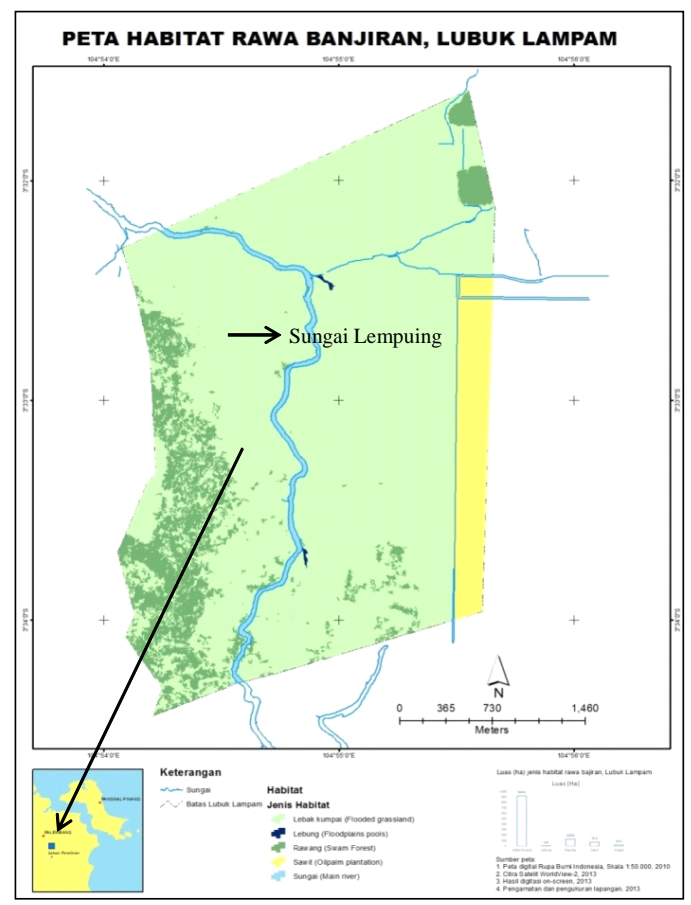

Gambar 1.Peta Lubuk Lampam.

Figure 1. Map of Lubuk Lampam. 


\section{Analisis Data \\ Nisbah Kelamin}

Nisbah kelamin diketahui berdasarkan perbandingan antara jumlah ikan jantan dan betina yang tertangkap setiap sampling. Jenis kelamin ditentukan setelah sampel ikan tersebut dibedah. Nisbah kelamin dianalisis menurut Effendi (1997) sebagai berikut:

$N_{k}=\frac{M}{F}$

Keterangan:

$N_{k}=$ Nisbah kelamin

$M=$ Jumlah total ikan jantan (ekor)

$F=$ Jumlah total ikan betina (ekor)

\section{Tingkat Kematangan Gonad}

Tingkat kematangan gonad (TKG) ikan jantan dan betina ditentukan secara morfologi mencakup warna, bentuk, dan ukuran gonad. Perkembangan gonad secara kualitatif ditentukan dengan mengamati TKG I-IV berdasarkan morfologi gonad, mengikuti klasifikasi Effendi (1979) Tabel 1.

\section{Indeks Kematangan Gonad}

Indeks kematangan gonad (IKG) diukur dari perbandingan berat tubuh dengan berat gonad ikan jantan dan betina menggunakan timbangan dengan ketelitian 0,01 gram. Indeks kematangan gonad dihitung dengan rumus sebagai berikut (Effendie, 1979):

$$
I K G(\%)=\left(B_{g}: B_{t}\right) x 100
$$

Keterangan :

$I K G=$ Indeks kematangan gonad

$B_{g} \quad=$ Berat gonad (gram)
$B_{t}=$ Berat tubuh (gram)

\section{Ukuran Pertama Kali Matang Gonad}

Ukuran ikan pertama kali matang gonad diduga dengan menggunakan metode Sperman Karber (King, 1995). Kriteria matang gonad adalah pada TKG III dan IV, adapun rumusnya adalah sebagai berikut:

$\log M=X_{k}+\frac{\bar{x}}{2}-\left(\bar{x} \sum P_{i}\right), \quad \mathrm{P}_{i}=\frac{r_{i}}{n_{i}}$

Keterangan:

$X_{k}=$ logaritma nilai tengah pada saat ikanmatang gonad $100 \%$

$\bar{x}=$ rata-rata selisih logaritme nilai tengah

$r_{i}=$ jumlah ikan matang gonad pada kelas ke-i

$n_{i}=$ jumlah total ikan sampel

\section{Fekunditas}

Fekunditas ikan dihitung pada TKG III dan IV dengan menggunakan metode gravimetrik (Effendie, 1979):

$$
F=\frac{G}{Q} x N
$$

Keterangan :

$F=$ Fekunditas (butir)

$G=$ Berat gonad (gram)

$Q=$ Berat gonad contoh (gram)

$N=$ Jumlah telur tiap gonad contoh

Berat gonad ikan diukur dengan cara membedah ikan contoh yang telah diawetkan, gonadnya diambil untuk kemudian ditimbang dengan timbangan eletronik dengan ketelitian 0,0001 g. Berat gonad contoh diambil dengan cara memotong sebagian gonad pada bagian anterior, tengah dan posterior selanjutnya ditimbang.

Tabel 1. Tingkat kematangan gonad ikan berdasarkan modifikasi Cassie (Effendie, 1979)

\begin{tabular}{|c|c|c|}
\hline $\begin{array}{c}\text { Tingkat Kematangan } \\
\text { Maturity stage }\end{array}$ & Betina/Female & Jantan/Male \\
\hline I & $\begin{array}{l}\text { Ovari seperti benang, panjang sampai } \\
\text { kedepan rongga tubuh. Warna jernih. } \\
\text { Permukaan licin. }\end{array}$ & $\begin{array}{l}\text { Testes seperti benang, lebih pendek } \\
\text { (terbatas) dan terlihat ujungnya dirongga } \\
\text { tubuh. Warna jernih. }\end{array}$ \\
\hline II & $\begin{array}{l}\text { Ukuran ovari lebih besar. Pewarnaan } \\
\text { lebih gelap kekuning-kuningan. Telur } \\
\text { belum terlihat jelas dengan mata. }\end{array}$ & $\begin{array}{l}\text { Ukuran testes lebih besar. Pewarnaan } \\
\text { putih seperti susu. Telur lebih jelas } \\
\text { daripada tingkat I. }\end{array}$ \\
\hline III & $\begin{array}{l}\text { Ovari berwarna kuning. Secara } \\
\text { morfologi telur mulai kelihatan } \\
\text { butirnya dengan mata. }\end{array}$ & $\begin{array}{l}\text { Permukaan testes tampak bergerigi. } \\
\text { Warna makin putih, testes makin besar. } \\
\text { Dalam keadaan diawet mudah putus. }\end{array}$ \\
\hline IV & $\begin{array}{l}\text { Ovari makin besar, telur berwarna } \\
\text { kuning, mudah dipisahkan. Butir } \\
\text { minyak tidak tampak, mengisi } 1 / 2- \\
2 / 3 \text { rongga perut, usus terdesak. }\end{array}$ & $\begin{array}{l}\text { Seperti pada tingkat III tampak lebih } \\
\text { jelas. Testes semakin pejal. }\end{array}$ \\
\hline
\end{tabular}

Table 1. The level of gonado maturity based on Cassie (Effendie, 1979) 


\section{Pola Reproduksi}

Pola reproduksi diestimasi dari ukuran diameter dan pola sebaran telur. Pengukuran diameter telur menggunakan Miview Microscope pembesaran 100 x. Pola sebaran diameter telur (TKG III dan IV) dianalisis secara diskriptif dengan melihat modus penyebarannya. Apabila terlihat dua modus penyebaran, pola pemijahannya berlangsung dalam waktu yang panjang atau telur yang dikeluarkan sebagian-sebagian (partial spawning). Jika terdapat penyebaran ukuran diameter telur dalam satu modus, pola pemijahan berlangsung dalam waktu yang singkat (total spawning) (Hanum, 2010).

\section{HASIL DAN BAHASAN}

Hasil

\section{Sebaran Frekuensi Ukuran Ikan Baung}

Selama penelitian sampel ikan baung yang diperoleh berjumlah 384 ekor terdiri dari jantan sebanyak 118 ekor dan betina 266 ekor. Ikan jantan terkecil berukuran $83 \mathrm{~mm}$ dan terbesar $385 \mathrm{~mm}$ sedangkan ikan betina, ukuran terkecil $100 \mathrm{~mm}$ dan terbesar $533 \mathrm{~mm}$. Untuk mengetahui variasi berat dan panjang tertentu dari ikan sampel secara individu atau kelompok dilakukan analisis hubungan panjang berat. Hubungan panjang berat ikan baung jantan mengikuti persamaan $\mathrm{W}=0.000006 \mathrm{~L}^{3.071}$ dengan nilai $\mathrm{b}$ sebesar 3,071, sedangkan ikan baung betina mengikuti persamaan $\mathrm{W}=0.00001 \mathrm{~L}^{2.974}$ dengan nilai b sebesar 2,974. Nilai koefisien korelasi (r) pada persamaan hubungan panjang-berat tersebut cukup tinggi, baik pada ikan baung jantan $(0,97)$ maupun betina $(0,96)$ (Gambar 2).

Berdasarkan hasil uji t diperoleh bahwa pola pertumbuhan ikan baung baik jantan alometrik positif sedangkan betina adalah alometrik negatif. Alometrik positif berarti pertambahan nilai panjang tubuh ikan lebih lambat daripada pertumbuhan nilai beratnya sebaliknya alometrik negatif berarti pertambahan nilai panjang tubuh ikan lebih cepat daripada pertumbuhan nilai beratnya.

\section{Nisbah Kelamin}

Rata-rata nisbah kelamin ikan baung yang ditemukan selama penelitian (satu tahun) sebesar 0,44:1, sedangkan berdasarkan waktu pengamatan (bulanan) nibah kelamin berkisar 0,13-2,50. Nisbah kelamin ikan baung menunjukkan tidak seimbang. Rasio kelamin ikan baung > 1 ditemukan ketika air mulai naik hingga banjir maksimal (Nopember 2012-Maret 2013), sedangkan di bulan April 2013-November 2013 saat banjir mulai turun/FBF hingga mulai naik < 1 (Gambar 3). Berdasarkan Gambar 3 dapat dilihat nisbah kelamin ikan baung $>1$ berlangsung pada saat air mulai naik (water rise/WR) hingga banjir maksimal (maximum flood/MF), ini menunjukkan bahwa pada saat pemijahan betina dibuahi lebih dari seekor jantan.

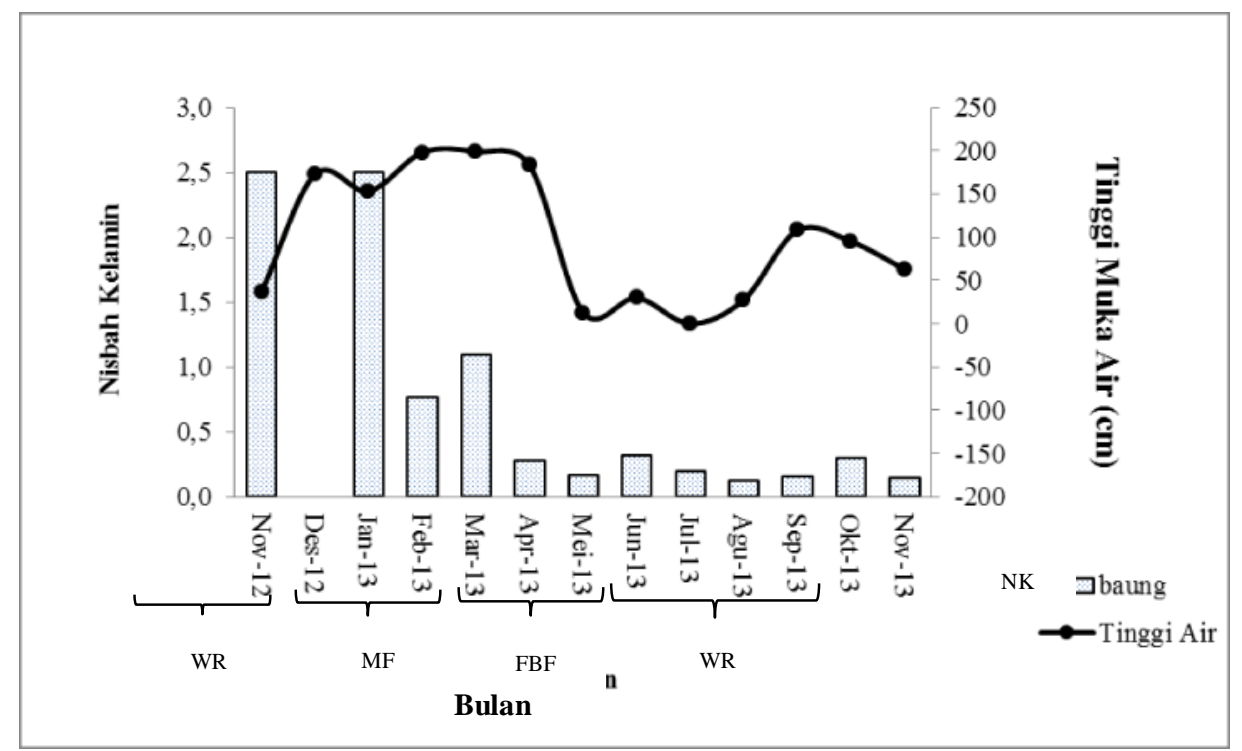

Keterangan: $\mathrm{WR}=$ Air naik, $\mathrm{MF}=$ Banjir maksimal, $\mathrm{FBF}=$ Banjir mulai turun, $\mathrm{NK}=$ Nisbah Kelamin Remarks: $W R=$ Water Rise, $M F=$ maximum flood, $F B F=$ flood begins to fall, $N K=$ sex ratio

Gambar 3. Nisbah kelamin ikan baung di Lubuk Lampam.

Figure 3. Sex ratio of green catfish in Lubuk Lampam. 


\section{Tingkat dan Indeks Kematangan Gonad}

Pada Gambar 4 a dapat dilihat bahwa saat musim penghujan air mulai naik (Nopember 2012, Desember 2012 dan Januari 2013 maka frekuensi ikan yang matang gonad (TKG III dan IV) akan meningkat namun ikan yang matang tidak ditemukan lagi ketika tinggi muka air mencapai puncak. Selanjutnya frekuensi ikan yang matang gonad ditemukan kembali ketika tinggi muka air mulai meningkat (bulan Oktober dan Nopember 2013). Pada Gambar 4 b, peningkatan muka air (Nopember 2012-Februari 2013)

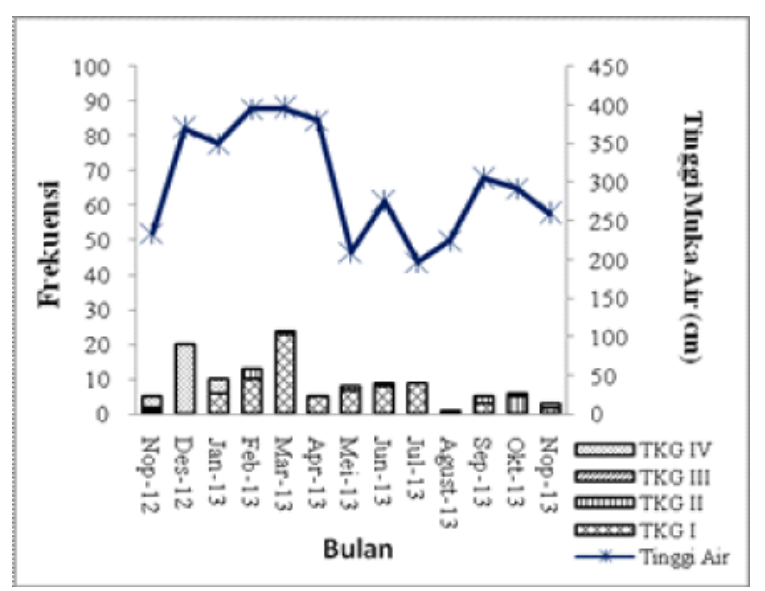

a kurang berpengaruh terhadap kematangan gonad ikan, namun ketika tinggi muka air mulai meningkat (bulan Oktober dan Nopember 2013) ikan yang matang gonad mulai banyak ditemukan.

Nilai indek kematangan gonad (IKG) ikan baung baik jantan maupun betina mengalami peningkatan seiring dengan peningkatan tingkat kematangan gonad. Peningkatan IKG yang nyata terlihat pada TKG IV baik ikan jantan maupun betina. Pada ikan baung betina nilai IKG berkisar 1,8-14,3\% sedangkan ikanjantan 1,3-3,9\% (Tabel2).

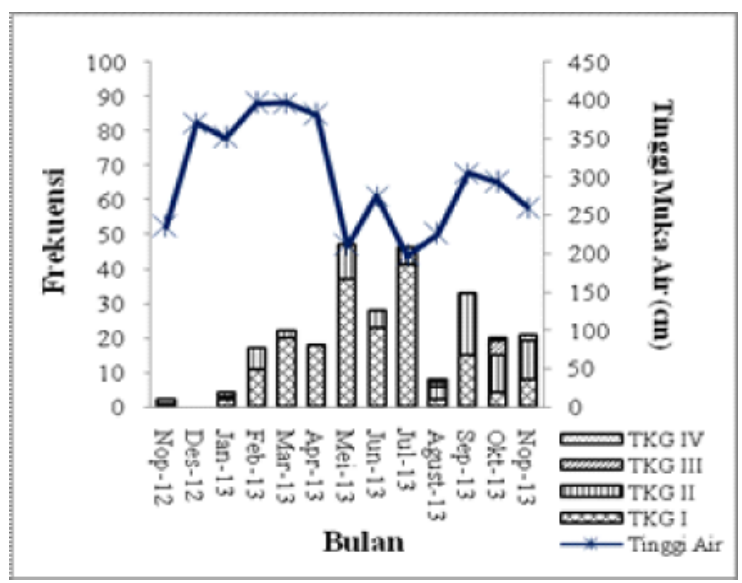

b

Gambar 4. Frekuensi tingkat kematangan gonad ikan jantan (a) dan betina(b) berdasarkan tinggi muka air.

Figure 4. Frequency of the level of gonado maturity, male (a) and female (b) based of water level.

Tabel 2. Rata-rata nilai indek kematangan gonad ikan baung berdasarkan tingkat kematangan gonad jantan dan betina

Table 2. The average value of gonado maturity index of green catfish based on the level maturity of male and female

\begin{tabular}{|c|c|c|c|c|c|}
\hline \multirow{2}{*}{ No. } & \multirow{2}{*}{$\begin{array}{c}\text { Tingkat } \\
\text { Kematangan } \\
\text { Gonad/Maturity } \\
\text { Stage }\end{array}$} & \multicolumn{2}{|c|}{$\begin{array}{l}\text { Indek Kematangan Gonad } \\
(\%) / \text { Gonado Somatic Index }\end{array}$} & \multicolumn{2}{|c|}{ Rata-rata $(\%)$ /Average } \\
\hline & & Jantan/Male & Betina/Female & Jantan/Male & Betina/ Female \\
\hline 1 & $\mathrm{I}$ & $0,01-0,06$ & $0,06-0,07$ & $0,026 \pm 0,005$ & $0,065 \pm 0,005$ \\
\hline 2 & II & $0,14-0,24$ & $0,16-0,24$ & $0,184 \pm 0,016$ & $0,197 \pm 0,009$ \\
\hline 3 & III & $0,2-1,5$ & $1,3-3,7$ & $0,47 \pm 0,08$ & $2,43 \pm 0,5$ \\
\hline 4 & IV & $1,3-3,9$ & $1,8-14,3$ & $2,78 \pm 0,47$ & $6,64 \pm 1,2$ \\
\hline
\end{tabular}

\section{Ukuran Panjang Ikan Pertama Kali Matang Gonad}

Berdasarkan hasil analisis pendugaan ukuran pertama kali (Lm) ikan yang matang gonad dengan metode Spearmen-Karber maka ukuran pertama kali ikan baung jantan matang gonad adalah $(232 \mathrm{~mm})$ dan betina adalah (332 mm) (Gambar 5).

\section{Fekunditas}

Hasil analisis data fekunditas, rata-rata fekunditas ikan baung berjumlah $47.882 \pm 13.624$ butir. Jumlah telur yang ditemukan memiliki kisaran yang cukup besar (15.386-
104.758 butir) hal ini disebabkan karena perbedaan ukuran dan umur masing-masing sampel ikan.

\section{Pola Reproduksi}

Distribusi (sebaran) ukuran diameter telur ikan baung setiap bulan memiliki kisaran yang berbeda (Lampiran 1). Pola sebaran diameter telur ikan baung hanya memiliki satu modus. Hal ini menunjukkan bahwa telur ikan baung matang serentak. Oleh karena itu ikan baung diduga melakukan satu kali pemijahan dalam setahun sehingga termasuk ikan yang memijah secara serempak (total spawner). 


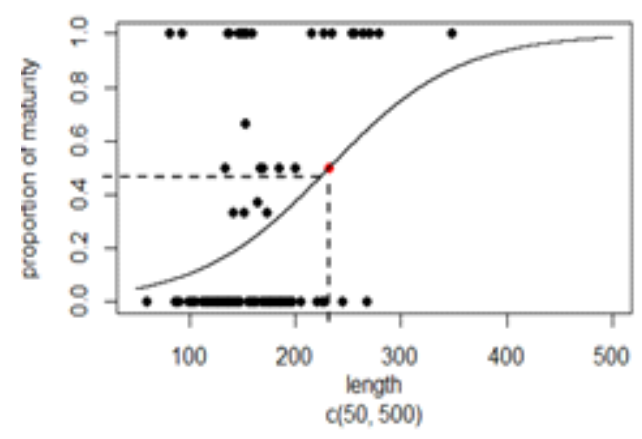

a. Jantan

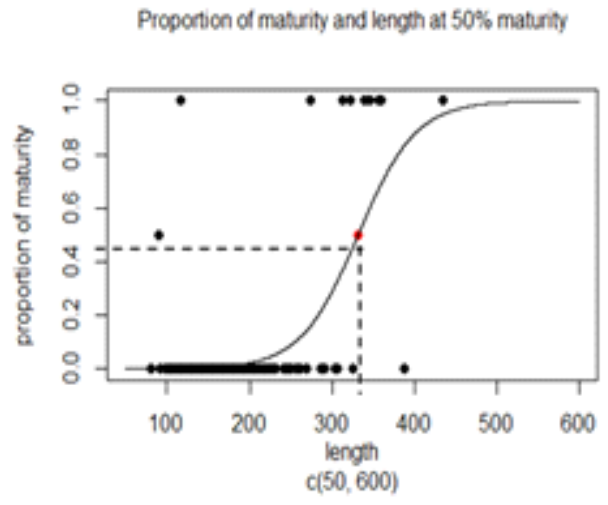

b. Betina

Gambar 5. Ukuran panjang ikan baung jantan dan betinapertamakali matanggonad (Lm).

Figure 5. Lenght of green catfish, male and female at first maturity ( $\mathrm{Lm})$.

\section{Bahasan}

Ikan baung merupakan salah satu jenis ikan air tawar dengan penyebaran yang cukup luas terutama di Pulau Sumatera, Jawa dan Kalimantan. Ikan ini ditemukan pada ekosistem perairan seperti rawa dan sungai (Sukendi, 2001, Diana et al. 1985) dan merupakan ikan dominan. Pertambahan panjang total ikan baung tersebut diikuti oleh pertambahan beratnya dengan pola pertumbuhan ikan jantan adalah alometrik positif, sedangkan betina adalah alometrik negatif. Hasil penelitian yang dilakukan Sukendi (2001) diperoleh pola pertumbuhan ikan baung baik jantan dan betina di Sungai Kampar adalah alometrik positif sedangkan hasil penelitian Wanda (2010) di sungai Batang Lebung dan Batang Sumani Kabupaten Solok, pola pertumbuhannya alometrik negatif.

Perbedaan pola pertumbuhan ikan dapat disebabkan oleh perkembangan biologi reproduksi dan ketersediaan makanan. Besarnya nilai b pada persamaan hubungan panjang dengan berat tergantung pada kondisi fisiologis dan lingkungan seperti suhu, $\mathrm{pH}$, letak geografis dan juga kondisi biologis seperti perkembangan gonad dan ketersediaan makanan (Froese, 2006; Jenning et al. 2001). Fafioye dan Oluajon (2005) menyatakan bahwa pertumbuhan ikan umumnya bersifat relatif artinya dapat berubah menurut waktu. Apabila terjadi perubahan terhadap lingkungan dan ketersediaan makanan diperkirakan nilai panjang dan berat juga akan berubah (Arteaga et al. 1997).

Nisbah kelamin ikan baung berfluktuasi setiap bulannya dan secara keseluruhan perbandingan jumlah ikan jantan lebih sedikit dari ikan betina. Nisbah kelamin atau proporsi antara ikan jantan dan betina di alam umumnya mengikuti 1:1 yaitu 50\% jantan dan $50 \%$ betina merupakan kondisi ideal untuk mempertahankan spesies (Jacob, 2005; Effendie, 1997; Khan et al. 1990). Adanya penyimpangan dari kondisi ideal tersebut disebabkan oleh faktor tingkahlaku ikan itu sendiri, perbedaan laju mortalitas, perbedaan distribusi, dan pertumbuhannya (Turkmen et al. 2002; Effendie, 1997), pergantian dan variasi seksual jantan dan betina dalam masa pertumbuhan, mortalitas dan lama hidup (Sadovy, 1996 dalam Simanjuntak, 2007). Banyaknya jumlah ikan betina yang tertangkap bila dibandingkan ikan jantan antara lain disebabkan karena ikan betina memiliki gerakan yang lebih lambat daripada ikan jantan (Sukendi, 2011). Ketidakseimbangan dapat juga disebabkan perbedaan tingkah laku ikan baung jantan dan betina, ikan betina cenderung bobotnya lebih besar dari ikan jantan sehingga ikan betina lebih mudah tertangkap (Manurung et al. 2013).

Ikan baung pada TKG III dan IV banyak ditemukan pada awal musim penghujan bulan Nopember-Desember 2012 dan Januari 2013, kemudian pada saat banjir maksimal hingga air turun (Februari-Juli 2013) tingkat kematangan gonad ikan di Lubuk Lampam didominasi TKG I dan II. Ikan yang matang gonad (TKG IV) setelah melakukan pemijahan akan kembali ke TKG II. Kemudian ikan dengan tingkat kematangan gonad III dan IV ditemukan lagi ketika air mulai naik (Agustus-Nopember 2013). Waktu pemijahan ikan berlangsung pada bulan Nopember, Desember 2012, Januari, Oktober dan Nopember 2013.

Hasil penelitian yang dilakukan Khan et al. (1990) bahwa pemijahan ikan baung di Chendenoh Resevoir, Malaysia berlangsung pada musim penghujan yaitu November sampai dengan Februari. Weber (1974) menyatakan musim pemijahan ikan tropis berhubungan erat dengan faktor hidrografi suatu wilayah. Di wilayah tropis, sebagian besar ikan memijah pada saat musim penghujan (Ballesteroset al. 2009) dan hanya sedikit yang memijah pada saat musim kemarau atau sepanjang tahun (Pusey et al. (2002), Torres-Mejia et al. (2008), AlkinsKoo, 2000). Tingkah laku pemijahan secara musiman tersebut dipengaruhi beberapa faktor seperti ketersediaan daerah pengasuhan, ketersediaan makanan, suhu dan siklus hidrologi (Ballesteros et al. 2009). 
Sumpter (1990) menyatakan siklus reproduksi setiap jenis ikan telah berkembang untuk merespon setiap perubahan habitat alaminya. Waktu pemijahan ikan setiap tahunnya berkembang sebagai respon terhadap faktor utama yang akan memaksimalkan kelangsungan hidup telur dan larva. Beberapa faktor utama antara lain kualitas air, ketersediaan makanan, penurunan jumlah predator dan sebagainya. Selain nilai IKG, perbedaan ukuran pertama kali matang gonad juga berbeda setiap jenis ikan tergantung letak geografis dan faktor lingkungan.

Ukuran pertama kali matang gonad ikan baung jantan lebih cepat matang dibandingkan betina. Cepatnya ikan jantan matang gonad diduga berkaitan erat dengan pengaruh lingkungan di perairan Lubuk Lampam. Ukuran pertama kali matang gonad ikan baung dalam penelitian ini berbeda dengan Khan et al. (1990) dimana ikan baung betina ( $325 \mathrm{~mm}$ ) lebih cepat matang dibandingkan jantan (355 mm). Selanjutnya Craig et al. (2004) menyatakan bahwa ukuran ikan pertama kali matang gonad biasanya lebih cepat pada ikan betina dari pada ikan jantan. Mustakim (2008) menegaskan bahwa perbedaan ukuran pertama kali matang gonad bisa terjadi pada suatu spesies ikan memiliki jenis kelamin yang berbeda. Kecilnya ukuran ikan pertama kali matang gonad dapat juga disebabkan tekanan penangkapan oleh nelayan. Menurut Trippel et al. (1997) dalam Nasution (2008), ikan yang mengalami tekanan karena tangkap lebih, cenderung matang gonad pada ukuran lebih kecil. Selanjutnya Nasution (2008) menyatakan ukuran ikan pertama kali matang gonad memiliki hubungan dengan pertumbuhan ikan dan pengaruh lingkungan terhadap pertumbuhan serta strategi reproduksinya.

Adapun perbedaan ukuran pertama kali matang gonad pada ikan baung diduga dipengaruhi oleh kelimpahan, kondisi lingkungan, ketersediaan makanan dan tekanan penangkapan. Menurut Senen et al. (2009) dalam Dewanti et al. (2012) bahwa ukuran pertama kali matang gonad pada ikan berbeda-beda, bahkan spesies yang sama namun berbeda habitatnya dapat matang gonad pada ukuran yang berbeda pula. Ikan yang mengalami tekanan karena penangkapan yang tinggi, cenderung matang gonad pada ukuran lebih kecil. Faktor lingkungan merupakan faktor pembatas dan berpengaruh secara langsung terhadap fekunditas ikan.

Fekunditas ikan baung cukup beragam dan memiliki kisaran yang cukup besar. Hasil penelitian Khan et al. (1990) diperoleh fekunditas ikan baung berkisar 6.90093.510 butir/ekor pada kisaran panjang ikan berkisar 345$450 \mathrm{~mm}$. Menurut Taylor dan Francis (2009) selain ketersediaan makanan faktor lingkungan yang berpengaruh terhadap reproduksi ikan adalah lama pencahayaan, suhu, curah hujan, arus dan tekanan air sedangkan Elvyra et al. (2010) dan (Siregar, 1989) menyatakan reproduksiikan dipengaruhi oleh ukuran tubuh dan faktorgenetis ikan. Selanjutnya Nikolsky (1969) dalam Effendie (2002) mengemukakan bahwa variasi fekunditas disebabkan oleh adanya kelompok ikan yang baru memijah dan sudah memijah, sehingga produksi telur cenderung lebih tinggi pada ikan yang baru memijah, akibatnya penyebaran produksi telur tidak merata.

Pola pemijahan ikan-ikan dipaparan banjiran berbedabeda, namun sebagian besar ikan memijah secara serempak. Pola pemijahan ikan baung adalah pemijahan secara serempak (totally spawner). Wootton (1998) dalam Ballesteros et al. (2009) menyatakan pola pemijahan ikan di daerah beriklim sedang sebagian besar dipengaruhi oleh suhu sedangkan didaerah tropis dipengaruhi oleh sistem hidrologi.

\section{KESIMPULAN}

Ikan baung mempunyai pola pertumbuhan yang berbeda dimana ikan jantan memiliki pola alometrik positif sedangkan betina alometrik negatif. Musim pemijahan ikan berlangsung pada saat air mulai naik yaitu bulan Nopember, Desember 2012, Januari, Oktober dan Nopember 2013. Pada musim pemijahan tersebut rasio kelamin jantan: betina $>1$. Ukuran pertama kali matang gonad ikan baung jantan dan betina masing-masing 232 $\mathrm{mm}$ dan $332 \mathrm{~mm}$ yang berarti ukuran matang gonad ikan baung jantan lebih cepat dibandingkan betinanya. Pola pemijahan ikan baung terjadi secara serempak (total spawner).

\section{DAFTAR PUSTAKA}

Alkins-Koo, M. 2000. Reproductive timing of fishes in a tropical intermittent stream. Environmental biology offishes 57(1): 49-66.

Arteaga,J; Garcia,P; Carlo, R. S \& Valle. 1997. Lengh-weight relationships of Cuban marine fishes. Journal Ichthyology 2(1) : 38-43.

Ballesteros, T. M; Torres-Mejia,M\& Ramírez-PinillaM. P. 2009. How does diet influence the reproductive seasonality of tropical freshwater fish? A case study of a characin in a tropical mountain river. Neotropical Ichthyology. 7 (4): 693-700.

Craig JF, Halls AS, Barr JJF, Bean CW. 2004. The Bangladesh floodplain fisheries. Fisheries Research. (66): 271-286.

Dewanti, Y. R; Irwani\& Rejeki, S. 2012. Studi Reproduksi dan Morfometri Ikan Sembilang (Plotosus canius) Betina yang Didaratkan di Pengepul Wilayah Krobokan Semarang. Journal of Marine Research. 1(2): 135-144. 
Diana, J. S., Chang, W. Y. B., Ottey, D. R \& Chuapoehuk, W. 1985. Production systems for commonly culture freshwater fishes of Southeast Asia. International Programs Report No. 7 Great Lakes and Marine Waters Center The University of Michigan: 126 p.

Djajadiredja, R., Hatimah, S \& Arifin, Z. 1977. Buku Pedoman Pengenalan Sumber Perikanan Darat. Bagian I. Direktorat Perikanan Departemen Perikanan. Jakarta: 96 hal.

Effendie, M. I. 2002. Biologi perikanan. Yayasan Pustaka Nusatama. Yogyakarta: 163 hal.

Effendie, M. I. 1997. Biologi Perikanan. Yogyakarta: Yayasan Pustaka Nusantara:163 hal.

Effendie, M. I. 1979. Metode Biologi Perikanan. Yayasan Agromedia: 111 hal.

Elvyra, R; Solihin, D.D., Affandi, R \& Junior, Z. 2010. Kajian Aspek Reproduksi Ikan Lais Ompok hypophthalmus di Sungai Kampar, Kecamatan Langgam, Kabupaten Pelalawan, Provinsi Riau Jurnal Natur Indonesia 12 (2):117-123.

Fafioye, O \& Oluajon, O. A. 2005. Length weight relationships of five fish species in Efe Lagoon. Nigeria, African. Journal of Biotechnologi. 4 (7): 749751.

Froese, R. 2006. Cube law, condition factor and weight length relationship: history, meta-analysis and recommendations. Journal of Applied Ichthyology. 22: 241-253.

Hadid, Y., Syaifudin, M \&Amin, M. 2014. Pengaruh Salinitas Terhadap Daya Tetas Telur Ikan Baung (Hemibagrus nemurus Blkr.) Jurnal Akuakultur Rawa Indonesia. 2 (1):78-92.

Hanum, D. Z. 2010. Aspek Biologi Reproduksi Dan Pendugaan Pola Rekruitmen Ikan Layur (Trichiurus lepturus)di Teluk Palabuhan Ratu, Sukabumi, Jawa Barat. Departemen Manajemen Sumberdaya Perairan Fakultas Perikanan dan Ilmu Kelautan Institut Pertanian Bogor. Skripsi: 55 hal.

Jacob, P. K. 2005. Studies on some aspects of reproduction of female Anabas testudineus (Bloch). Departemen of Marine Biology, Microbiology and Biology. Cochin University of Science and Technology India. Thesis: 261 hal.
Jenning, S; Kaiser, M. J \& Reynolds, J. D. 2001. Marine fishery ecology. Blackwell Publishing Company Sciences, Oxford: 417p.

Jubaedah, D. 2015. Pengelolaan Rawa Banjiran Berbasis Analisis Dinamika Fluktuasi Muka Air Di Lubuk Lampam, Sumatera Selatan. Sekolah Pasca Sarjana Institut Pertanian Bogor. Disertasi: 127 hal.

Khan, M. S.,Ambak, M. A., Ang, K. J\& Mohsin, A. K. M. 1990. Reproductive biology of a tropical catfish, Mystus nemurus Cuvier and Valenciennes, in Chenderoh reservoir, Malaysia. Journal Aquaculture and Fisheries Management 21(2):173-179.

King, M. 1995. Fisheries Biology. Assesment and Management. Fishing News Books, Blackwell Science Ltd: $400 \mathrm{p}$.

Kottelat, M; Whitten, J. A; Wirjoatmodjo, S \& Kartikasari, S. N. 1996. Freshwater Fishes of Western Indonesia and Sulawesi.Jakarta: Periplus EditionLtd: 344 hal.

Manurung, V. R; Djayus, M \& Desrita. 2013. Studi Aspek Reproduksi Ikan Baung (Mystus nemurus Cuvier Valenciennes) Di Sungai Bingai Kota Binjai Provinsi Sumatera Utara. Jurnal Aquacoastmarine 1(1):1-9.

Mustakim, M. 2008. Kajian Kebiasaan Makanan dan Kaitannya dengan Aspek Reproduksi ikan betok (Anabas testudineus Bloch) pada Habitat yang Berbeda di Lingkungan Danau Melintang Kutai Kartanegara Kalimantan Timur. Tesis SPS IPB. Bogor: 114 hal.

Nasution, S. H. 2008. Ekobiologi dan Dinamika Stok Sebagai Dasar Pengelolaan Ikan Endemik Bonti-Bonti (Paratherina striata Aurich) di Danau Towuti, Sulawesi Selatan. Sekolah Pascasarjana Institut Pertanian Bogor. Disertasi: 173 hal.

Pusey, B. J; Arthington, A. H; Close, P. G\& Bird, J. R. 2002. Larval fishes in rainforest streams: recruitment and microhabitat use. Proceedings of the Royal Society of Queensland. 110: 27-46.

Samuel \& Adjie, S. 1994. Aspek Reproduksi dan Kebiasaan Makan Ikan Baung (Mystus nemurus CV) di Daerah Aliran Sungai Batang Hari Jambi. Buletin Penelitian Perikanan Darat XII. (2): 59-65.

Simanjuntak, C. P. H. 2007. Reproduksi Ikan Selais, Ompok hypopthalmus (Bleeker) Berkaitan Dengan Perubahan Hidromorfologi Perairan di Rawa Banjiran Sungai Kampar Kiri.Tesis. Bogor. Program Pascasarjana. Institut Pertanian Bogor: 59 hal. 
Siregar S. 1989. Kemungkinan pembudidayaan ikan kapiek (Puntius schwanefeldi Blkr.) dari Sungai Kampar, Riau [tesis]. Fakultas Pascasarjana, Institut Pertanian Bogor. Bogor: 19 hal.

Sukendi. 2001. Biologi Reproduksi dan Pengendaliannya Dalam Upaya Pembenihan Ikan Baung (Mystus nemurus CV) Dari Perairan Sungai Kampar, Riau. Program Pasca Sarjana Institut Pertanian Bogor. Disertasi: 207 hal.

Sumpter, J. P. 1990. General concepts of seasonal reproduction. In: Reproductive seasonality in Teleosts: Environmental influences (Munro, A. D., A.P. Scott and T. J. Lam (eds.) CRC Press, Boca Raton, F. L: 13 p.

Taylor \& Francis. 2009. Methods in reproductive aquaculture marine and freshwater species. CRC Press : New York, Suite: 300 p.
Torres-Mejia, M \& Ramírez-Pinilla, M. P. 2008. Dry-season breeding of a characin in a tropical mountain river. Copeia1:99-104.

Turkmen, M; Erdogan, O; Yildirim, A \& Akhyurt, I. 2002. Reproductive tactics, age and growth of Capoeta capoeta umla Heckel 1843 from the Askale region of the Karasu River, Turkey. J Fish Res 54:317-328.

Wanda, A. P. 2010. Aspek Biologi Ikan Baung (Hemibagrus nemurus C.V) di Sungai Batang Lembung dan Batang Sumani Kabupaten Solok Sumatera Barat. Fakultas Matematika dan Ilmu Pengetahua Alam Universitas Nadalas. Skripsi: 47 hal.

Weber, W. 1974. The influence of hydrographical factors on the spawning time of tropical fish. Proc. Int. Seminar. Fish. Res. and theirManagement in S. E. Asia: 269-281. 
Lampiran 1. Sebaran diameter telur ikan baung

Appendix 1. Diameter distribution of green catfish egg
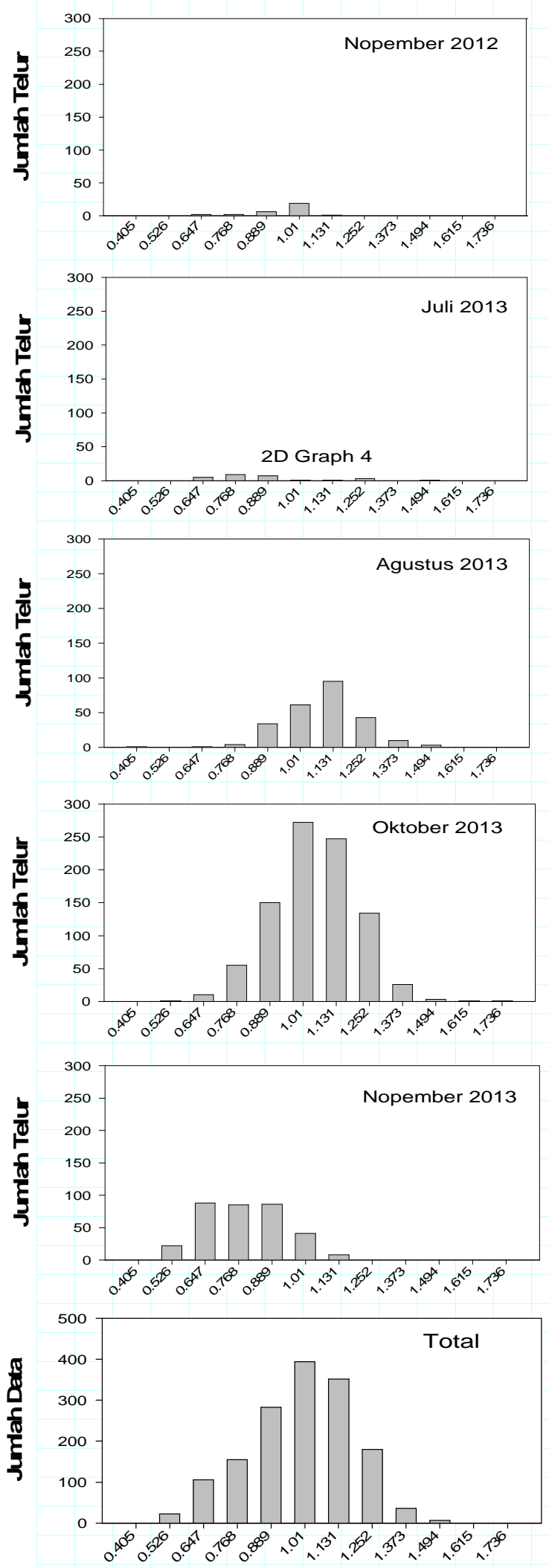

\section{Diameter Telur}

